\title{
MANAJEMEN LABA AKRUAL DAN RIIL SEBELUM DAN SETELAH ADOPSI WAJIB IFRS DI UNI EROPA
}

\author{
Yayu Putri Senjani
}

Ikatan Akuntan Indonesia

\begin{abstract}
Management of Accrual and Real Earning: Before and After IFRS Adoption in European Union. This study aims to provide empirical evidence on earnings management practices in the Europe Union in three years before and after the mandatory IFRS adoption. Earning management practices what are observed is accrual earnings management (the level of discretionary accruals) and real earnings management (abnormal cash flow from operation and abnormal production costs). Data is retrieved from OSIRIS database by using the purposive sampling method and was tested with paired sample t-test. The results showed empirically that there is no difference between accrual and real earnings management in the period before and after the mandatory IFRS adoption. Other results also showed that accruals and real earnings management are positively correlate for abnormal production costs after the mandatory IFRS adoption.
\end{abstract}

Keywords: accrual earning, real earning, IFRS, paired-sample t-test

\begin{abstract}
Abstrak. Manajemen Laba Akrual dan Riil: Sebelum dan Setelah Adopsi Wajib di Uni Eropa. Tujuan dari kajian ini ialah untuk menyediakan bukti empiris atas praktik pengelolaan laba di Uni Eropa sebelum dan setelah kewajiban adopsi IFRS. Praktik pengelolaan laba yang diamati ialah pengelolaan laba akrual (tingkat akrual diskresioner) dan pengelolaan laba riil (arus kas abnormal dari operasi dan biaya produksi abnormal). Data didapat dari pangkalan data OSIRIS dengan menggunakan teknik sampel purposive dan diuji menggunakan uji t berpasangan. Hasil yang didapat menunjukkan bahwa secara empiris tidak terdapat perbedaan pengelolaan laba akrual dan riel pada periode sebelum dan setelah adopsi wajib IFRS. Hasil yang lain menunjukkan bahwa pengelolaan akrual dan riel berkorelasi positif terhadap biaya produksi abnormal setelah adopsi IFRS.
\end{abstract}

Kata Kunci: laba akrual, laba riil, IFRS, uji t berpasangan 


\section{PENDAHULUAN}

International Financial Reporting Standard (IFRS) merupakan standar pelaporan keuangan yang disusun sebagai solusi dalam masalah perbedaan standar-standar lokal di berbagai negara. IFRS pertama kali diterapkan secara penuh oleh Negara-negara Uni Eropa yang kemudian disusul Australia, Brazil, Kanada, Singapura dan beberapa negara di dunia termasuk Indonesia. Tujuan International Accounting Standard Board (IASB) dalam menyusun standar yang berterima internasional adalah untuk meningkatkan kualitas angka akuntansi agar dapat mencerminkan kondisi ekonomi dan kinerja perusahaan yang sebenarnya. Kualitas akuntansi ditandai oleh manajemen laba yang kecil, pengakuan rugi tepat waktu dan memiliki relevansi nilai yang tinggi. (Barth et al., 2008).

IFRS menerapkan standar berdasarkan prinsip (principle-based) yang diharapkan dapat meningkatkan kualitas akuntansi yang tinggi. Kualitas akuntansi dapat meningkat jika kebijakan oportunistik manajemen dapat dibatasi, misalnya dalam melakukan manajemen laba (Barth et al., 2008). Hutagaol (2010), Barth et al. (2008), Rahmellia (2009) menunjukkan bahwa manajemen laba setelah adopsi IFRS lebih rendah dibandingkan dengan periode sebelumnya, dan nilai relevansi laba setelah periode pengadopsian lebih tinggi dari pada periode sebelumnya.

Penelitian tentang pengaruh IFRS terhadap perubahan perilaku manajemen laba masih memiliki hasil yang bertentangan. Christensen et al. (2008), Lippens (2008), Callao dan Jarne (2010), serta Ahmed (2010) menunjukkan terjadinya peningkatan manajemen laba akrual dan riil pada periode setelah adopsi IFRS. Berbeda dengan hasil penelitian oleh Hutagaol (2010), Barth et al. (2008), Rahmellia (2009), temuan ini menunjukkan bahwa IFRS mendukung akuntansi diskresioner dan perilaku oportunistik manajemen yang berdampak pada kualitas informasi keuangan.

Manajemen laba secara umum dibagi dalam dua kategori yaitu (1) manajemen laba melalui kebijkan akuntansi atau disebut juga manajemen laba akrual dan (2) manajemen laba melalui aktivitas riil. Perubahan penerapan standar akuntansi dari standar lokal menjadi IFRS cenderung berpengaruh 
negatif terhadap perilaku manajemen laba secara akrual. Namun di beberapa penelitian masih menunjukkan terjadi peningkatan manajemen laba berupa perataan laba pada periode setelah penerapan IFRS (Christensen et al., 2008; Lippens, 2008; Callao dan Jarne, 2010; serta Ahmed, 2010)

Penulis menduga terjadi perubahan perilaku praktik manajemen laba setelah perusahaan menerapkan IFRS dari basis akrual menuju basis riil karena perubahan standar dapat mempengaruhi perilaku manajemen laba (Cohen et al., 2008). IFRS diharapkan dapat mengurangi praktik manajemen laba secara akrual melalui perubahan kebijakan akuntansi (Barth et al., 2008), namun diduga akan terjadi peningkatan manajemen laba secara riil melalui tindakan kebijakan operasional perusahaan (Lippens, 2008).

Penelitian yang menunjukkan perubahan standar akuntansi berdampak pada perilaku manajemen laba akrual telah banyak dilakukan, namun tidak demikian dalam hal manajemen laba riil. Pertanyaan yang muncul adalah apakah IFRS dapat mengurangi tingkat manajemen laba akrual dan riil ataukah hanya salah satunya? Penelitian untuk menjawab pertanyaan tersebut penting karena manajemen laba secara akrual maupun ril merupakan tindakan yang tidak etis walaupun dilegalkan dalam standar yang berlaku. Penelitian ini bertujuan untuk mengidentifikasi tingkat praktik manajemen laba secara akrual maupun riil pada masa sebelum dan setelah adopsi wajib IFRS di Negara-negara Uni Eropa.

Tujuan IASC (International Accounting Standards Committee) dan badan pendukung IASB, adalah mengembangkan set standar pelaporan keuangan berkualitas tinggi yang diterima secara internasional. Untuk mencapai tujuan itu, IASC/IASB telah menerbitkan standar berdasarkan prinsip (principlebased), mengambil langkah-langkah untuk menghilangkan akuntansi alternatif yang diperbolehkan, serta mengharuskan pengukuran akuntansi yang merefleksikan posisi ekonomi dan kinerja perusahaan dengan lebih baik.

IFRS yang menggambarkan pendekatan berbasis prinsip (principlesbased approach) lebih baik daripada pendekatan berbasis aturan (rules-based approach) untuk pengembangan standar akuntansi. Standar yang berbasis prinsip berfokus pada ketentuan prinsip-prinsip umum yang diperoleh dari 
kerangka konseptual, gambaran pengakuan, pengukuran, dan pelaporan yang diperlukan untuk transaksi-transaksi yang tercakup oleh standar (Pacter, 2003). Cara penerapan IAS/IFRS bervariasi. Amerika Serikat mulai mengadopsi IFRS melalui konvergensi IFRS dengan US GAAP, sedangkan negara-negara Uni Eropa memilih IFRS sebagai standar akuntansi yang digunakan tanpa melalui penyesuaian dengan standar akuntansi lokal di setiap negara. Australia, Kanada dan Singapura yang telah lama mengadopsi IAS sebagai standar lokal dengan sedikit pengecualian, juga meningkatkan upayanya untuk mengadopsi IFRS (Decker et al., 2003). Beberapa tahun ini, IAI (Ikatan Akuntan Indonesia) menyusun PSAK (Pernyataan Standar Akuntansi Keuangan) yang disesuaikan dengan IFRS dan mulai diberlakukan secara wajib pada perusahaan yang terdaftar di BEI (Bursa Efek Indonesia) sejak 1 Januari 2012.

IFRS diadopsi oleh perusahaan secara wajib (mandatory) maupun sukarela (voluntary). IFRS diadopsi secara wajib ketika regulator di suatu negara menetapkan kebijakan bagi perusahaan yang go public untuk melaporkan akuntansi berdasarkan IFRS. Sedangkan pengadopsian secara sukarela dilakukan oleh perusahaan yang memilih menerapkan IFRS sebelum adanya perintah dari regulator untuk menerapkan IFRS.

Manajemen laba terjadi ketika manajer menggunakan pertimbangan dalam pelaporan keuangan dan dalam menyusun transaksi untuk mengubah statemen keuangan untuk menyesatkan beberapa stakeholder mengenai dasar kinerja ekonomi perusahaan atau mempengaruhi hasil kontraktual yang tergantung pada praktik akuntansi yang dilaporkan (Healy dan Wahlen, 1999). Manajemen laba berbasis akrual diestimasi dengan menggunakan model discretionary accrual (akrual diskresioner). Manajemen laba akrual dilakukan dengan cara mengubah metode akuntansi yang digunakan ke metode akuntansi alternatif lainnya yang lebih menguntungkan manajemen. Perubahan metode tersebut diusahakan tidak berpengaruh pada aliran kas. Roychowdhury (2006) mendefinisikan manipulasi aktivitas operasional sesungguhnya sebagai bentuk manajemen laba riil. Penilaian manajemen laba riil berfokus pada tiga metode manipulasi dan pengaruhnya terhadap tingkat abnormal dari tiga variabel yaitu manipulasi penjualan, pengurangan pembiayaan diskresional dan kelebihan 
produksi. Penelitian tentang pengaruh IFRS terhadap perubahan perilaku manajemen laba masih memiliki hasil yang bertentangan. Penelitian yang dilakukan Christensen et al. (2008), Lippens (2008), Callao dan Jarne (2010) serta Ahmed (2010) menunjukkan bahwa terjadi peningkatan perataan laba pada periode setelah adopsi IFRS. Beberapa hasil penelitian lain mengalami perbedaan hasil. Penurunan manajemen laba akrual teridentifikasi pada periode setelah adopsi IFRS (Barth et al., 2008; Aussenegg et al., 2009; Rahmellia, 2009; Arifin, 2009; Hutagaol, 2010).

Capkun et al. (2010) memberikan referensi yang mendukung kedua hasil penelitian tersebut dengan membedakan sampel manjadi tiga kelompok, early adopters, mandatory adopters dan late adopters. Manajemen laba akrual meningkat pada perusahaan di negara yang tergolong mandatory adopters, namun terjadi penurunan pada perusahaan yang tergolong early adopters. Dengan demikian belum dapat disimpulkan bahwa apakah IFRS dapat meningkatkan atau menurunkan tingkat manajemen laba akrual pada perusahaan tanpa membedakan waktu mengadopsi IFRS.

Ahmed (2010) menemukan bahwa adopsi IFRS secara wajib menghasilkan laba yang lebih rata, pelaporan akrual yang lebih agresif, mengurangi ketepatwaktuan dalam pengakuan kerugian pada perusahaan yang mengadopsi IFRS tahun 2005 yang dikontrol dengan perusahaan yang tidak mengadopsi IFRS. IFRS adalah standar berdasarkan prinsip yang memiliki petunjuk implementasi yang minim, menyebabkan manajer memiliki kesempatan untuk mengatur laba dan menunda pengakuan kerugian serta sedikit perubahan mekanisme perundangan-undangan.

Berbeda dengan penelitian di atas, Barth et al. (2008) menguji hubungan IAS dengan kualitas akuntansi yang diproksikan dengan tingkat manajemen laba, relevansi nilai dan pengakuan kerugian. Hasilnya menunjukkan bahwa perusahaan yang mengadopsi IAS memiliki kualitas akuntansi yang lebih tinggi dibandingkan dengan yang tidak mengadopsi IAS. Tingkat manajemen laba dalam penelitian ini diukur dengan tingkat perataan laba (income smoothing). Sama halnya dengan Barth et al. (2008), Aussenegg et al. (2009) menunjukkan terdapat penurunan yang signifikan dalam tingkat manajemen laba 
perusahaan-perusahaan Prancis dan Jerman. Ia membandingkan ketika perusahaan mengadopsi GAAP lokal dengan ketika mengadopsi IFRS. Inggris dan Irlandia serta negara-negara Eropa Utara memiliki tingkat manajemen laba yang lebih rendah pada periode sebelum adopsi IFRS jika dibandingkan dengan negara-negara Eropa lainnya.

Walaupun masih terdapat pertentangan hasil penelitian mengenai pengaruh adopsi IFRS terhadap tingkat manajemen laba akrual, secara teori dan dari beberapa argumen yang dibangun oleh penelitian terdahulu, IFRS cenderung dinilai mampu meningkatkan kualitas akuntansi dengan mengurangi praktik manajemen laba akrual. Hal ini terlihat dari tujuan dari IASB menyusun IFRS. Hal ini dilatarbelakangi dari kegagalan rule-based standard di Amerika Serikat untuk memberikan informasi akuntansi yang lebih berkualitas. Kasus Enron adalah kasus terbesar yang terjadi di Amerika Serikat dan menjadi perhatian dunia. Mengingat Amerika Serikat merupakan kiblat standar akuntansi, standar profesi akuntansi dan pasar modal dunia, namun tidak mampu menjaga kualitas akuntansi dari standar yang mereka miliki, yaitu Statement of Financial Accounting Standard (SFAS) yang disusun oleh Financial Accounting Standard Board (FASB).

Beberapa literatur di atas menunjukkan bahwa IFRS merupakan standar akuntasi yang lebih memberikan penekanan pada prinsip dari sebuah transaksi saat mencatatnya, sehingga dapat mengurangi tindakan oportunistik manajemen yang memanfaatkan kebijakan akuntansi yang legal demi kepentingan dirinya maupun perusahaan. Dengan demikian penulis menyusun hipotesis alternatif sebagai berikut:

H1 : tingkat manajemen laba akrual menurun setelah adopsi IFRS

Menurunnya tingkat manajemen laba akrual bukan berarti manajemen laba berkurang, tetapi manajemen masih mungkin untuk melakukan manajemen laba secara riil. Manajemen laba riil tidak dilakukan dengan mengubah kebijakan akuntansi yang telah dibatasi oleh standar (IFRS), melainkan berupa tindakan riil yang seolah-olah merupakan kebijakan manajemen seperti perilaku menumpuk persediaan. 
Manajemen laba akrual dan riil merupakan cara untuk melakukan manajemen laba dan dilakukan dengan motivasi yang sama. Motivasi untuk melakukan manajemen laba yang diungkapkan oleh Scott (2000) diantaranya adalah motivasi kontraktual, motivasi politik, motivasi perpajakan, perubahaan CEO (Chief Excecutive Officer), IPO (Initial Public Offerings/Penawaran Publik Perdana) dan komunikasi informasi terhadap investor.

Lippens (2008) mengidentifikasi manajemen laba akrual dan riil di beberapa negara Uni Eropa dan negara-negara lain yang menerapkan IFRS secara wajib sejak 1 Januari 2005. Lippens (2008) mengekspektasikan bahwa tingkat manajemen laba akrual akan meningkat pada periode setelah adopsi wajib IFRS dan tingkat manajemen laba riil akan menurun pada periode tersebut. Namun, pengujian pada periode 2000-2006 menunjukkan hasil bahwa tingkat manajemen laba akrual dan riil meningkat signifikan pada periode setelah adopsi wajib IFRS. Hal ini konsisten dengan penelitian yang dilakukan oleh Christensen et al. (2008), Callao dan Jarne (2010), serta Ahmed (2010) dan menunjukkan adanya pertentangan hasil penelitian kembali mengenai pengaruh adopsi IFRS terhadap manajemen laba akrual.

Kelemahan penelitian Lippens (2008) adalah periode yang digunakan sebagai kategori masa setelah adopsi IFRS (2005-2006) terlalu singkat, sehingga menjadi bias karena efek masa transisi pada masa itu. Selain itu, perbandingan antara periode sebelum dan setelah adopsi IFRS tidak sebanding. Periode sebelum adopsi adalah tahun 2000-2004 (lima tahun) dan periode setelah adopsi adalah tahun 2005-2006 (dua tahun). Ketika menggunakan proksi perataan laba sebagai ukuran manajemen laba akrual dan perbandingan lamanya periode sebelum dan setelah adopsi yang tidak sebanding dapat menyebabkan pengukuran yang tidak sesuai dengan teori.

Berdasarkan beberapa literatur di atas, maka hipotesis kedua yang diajukan adalah sebagai berikut:

$\mathrm{H} 2 \mathrm{a}$ : tingkat manajemen laba riil dengan cara manipulasi penjualan meningkat setelah adopsi IFRS

$\mathrm{H} 2 \mathrm{~b}$ : tingkat manajemen laba riil dengan cara meningkatkan produksi (Over Production) meningkat setelah adopsi IFRS

$\mathrm{H} 2 \mathrm{c}$ : tingkat manajemen laba riil meningkat setelah adopsi IFRS 
Demski (2004) menyusun model substitusi antara manajemen laba akrual dan riil. Ia berargumen bahwa jika suatu standar semakin ketat, maka akan mengurangi manajemen laba akrual. Ewert dan Wagenhofer (2005) meneliti pengaruh substitusi antara manajemen laba akrual dan ril. Anggapannya, badan pembuat standar hanya dapat menekan tindakan manajemen laba akrual melalui penyusunan standar yang ketat. Mereka memprediksi bahwa manajer meningkatkan manfaat marjinal dari manajemen laba riil (Arifin, 2008).

Lebih lanjut Lippens (2008) membangun sebuah argumen bahwa manajemen laba akrual dan riil memiliki hubungan yang saling menggantikan. Ketika manajemen laba akrual meningkat, maka manajemen laba riil menurun. Untuk menjelaskan hal tersebut perlu diidentifikasi dengan melihat korelasi antara manajemen laba akrual dengan manajemen laba riil.

H3: terdapat hubungan negatif antara tingkat manajemen laba akrual dengan manajemen laba riil

\section{METODE}

Sampel penelitian ini adalah perusahaan manufaktur menurut NAICS 2007 (Two-Digit Primary Code: 31-33) yang terdaftar di pasar bursa di Negaranegara Uni Eropa. Data perusahaan mengenai variabel-variabel yang diuji diperoleh dari database OSIRIS. Tiga tahun periode sebelum penerapan IFRS dan periode setelah adopsi. Penggunaan discretionary accrual sebagai proksi manajemen laba akrual dihitung dengan menggunakan Modified Jones Model (Dechow et al., 1995). Untuk mendapatkan angka akrual diskresioner maka dilakukan tahapan perhitungan sebagai berikut (Dechow et al., 1995): Pertama, menentukan nilai total akrual (TA): Kedua, menentukan nilai parameter $\alpha_{1}, \alpha_{2}$, dan $\alpha_{3}$ dengan menggunakan model Modified Jones (1991). Ketiga, nilai parameter $\alpha_{1}, \alpha_{2}$, dan $\alpha_{3}$ yang diperoleh dari regresi di atas digunakan untuk menghitung nilai Non-akrual diskresioner (Non Discretionary Accrual/NDA). Keempat, menentukan nilai akrual diskresioner.

Manipulasi aktivitas riil berawal dari perubahan kebijakan dalam praktik operasi normal yang dimotivasi oleh keinginan manajer untuk menyesatkan stakeholders dan meyakinkan mereka bahwa tujuan pelaporan 
keuangan telah tercapai (Roychowdhury, 2006). Manajemen laba riil diukur dengan model yang dikembangkan oleh Roychowdhury (2006):

Arus kas dari operasi (CFO) abnormal merupakan selisih antara arus kas operasi aktual dengan arus kas operasi normal. Estimasi arus kas normal diperoleh dari regresi dengan formula yang direplikasi dari penelitian Roychowdurry (2003).

Setelah koefisien diketahui, selanjutnya adalah menggunakan koefisien tersebut untuk menghitung arus kas operasi aktual. Arus kas operasi abnormal sebagai indikasi terjadinya manajemen laba riil diperoleh dengan cara tingkat actual dikurangi dengan tingkat normal. Selain model HPP, model yang diperlukan untuk mengukur tingkat produksi abnormal adalah model pertumbuhan persediaan.

Pengujian hipotesis pertama dan kedua dilakukan dengan membandingkan nilai rata-rata akrual diskresioner (proksi manajemen laba akrual) antara periode sebelum dengan setelah adopsi IFRS dengan uji beda atau paired sample t-test (Uji beda sampel berpasangan). Namun jika data tidak berdistribusi normal maka uji beda ini harus diganti dengan uji statistik non parametrik yaitu uji wilcoxon untuk sampel berpasangan (Wilcoxon Matched Pairs Signed Rank Test).

Hipotesis tiga bertujuan mengidentifikasi adanya efek substitusi antara manajemen laba akrual dengan manajemen laba riil. Pengujian korelasi antar basis manajemen laba digunakan untuk menjelaskan apakah terdapat hubungan negatif di antara keduanya? Jika manajemen laba akrual menurun pada periode setelah adopsi IFRS, maka manajemen laba riil meningkat.

\section{PEMBAHASAN}

Pemilihan sampel dilakukan dengan metode Purposive Sampling. Hasil pemilihan sampel yang memenuhi kriteria pemilihan adalah terdapat 50 perusahaan yang tersebar di 8 Negara (dari total 27 negara Uni Eropa) dan 15 jenis Industri Manufaktur (dari total 21 jenis industri kode NAICS 2007 No. 3133) di Uni Eropa. Dari 50 perusahaan tesebut, terdapat 300 observasi yang dapat dilakukan. 
Nilai rata-rata Abs_DA untuk periode setelah adopsi IFRS lebih kecil dibandingkan dengan nilai rata-rata Abs_DA sebelum adopsi IFRS (0.041657557445<0.044543019809). Hasil tersebut mengindikasikan bahwa praktik manajemen laba akrual menurun setelah adopsi IFRS. Namun hal ini tidak dapat dijadikan untuk mengkonfirmasi hipotesis pertama sebelum diketahui tingkat signifikansi perbedaan kedua variabel tersebut. Begitu juga dengan manajemen laba riil (RM_Proxy) yang mengalami peningkatan pada periode setelah adopsi IFRS.

Sebelum pengujian hipotesis, dilakukan uji distribusi normal terhadap residual model penelitian dan diperoleh hasil bawa data tidak berdistribusi normal. Karena data berdistribusi tidak normal, maka uji beda untuk mengkonfirmasi hipotesis pertama dilakukan dengan uji Wilcoxon Matched Pairs Signed Rank Test.

Dengan melihat angka Asymp. Sig. (2-tailed) dapat disimpulkan bahwa tingkat manajemen laba akrual antara periode sebelum dan setelah adopsi IFRS tidak berbeda signifikan $(0.847>0.050)$. Hipotesis pertama yang menyatakan bahwa tingkat manajemen laba akrual menurun setelah adopsi IFRS tidak didukung secara statistik.

Hasil ini menunjukkan bahwa perusahaan manufaktur di Uni Eropa tetap melakukan praktik manajemen laba akrual ketika meretia masih menggunakan standar akuntansi lokal maupun ketika menggunakan IFRS. Temuan ini tidak mengkonfirmasi hasil-hasil penelitian sebelumnya yang menyatakan bahwa manajemen laba akrual menurun setelah adopsi IFRS (Barth et al., 2008; Aussenegg et al., 2009) dan manajemen laba akrual meningkat setelah adopsi IFRS (Christensen et al., 2008; Callao dan Jarne, 2010).

Pada pengujian hipotesis kedua, proksi manajemen laba riil berdistribusi normal, maka alat uji yang digunakan adalah paired sample t-test. Hipotesis $2 \mathrm{a}$, $2 \mathrm{~b}$ dan $2 \mathrm{c}$ tidak terdukung melalui uji statistik yang telah dilakukan. Perbedaan tingkat arus kas abnormal (H2a), tingkat biaya produksi abnormal (H2b) dan tingkat manajemen laba riil (H2c) yang merupakan jumlah dari nilai standardized arus kas operasi abnormal dan biaya produksi abnormal, tidak 
signifikan antara periode sebelum dan setelah adopsi IFRS (sig.>0.05). Temuan ini menunjukkan bahwa tidak ada perubahan dalam tingkat manajemen laba riil ketika perusahaan mengadopsi IFRS. Hasil penelitian ini berbeda dengan yang ditemukan oleh Lippens (2008). Ia menunjukkan bahwa manajemen laba riil meningkat setelah adopsi IFRS secara wajib.

Pengujian hipotesis ketiga dilakukan untuk mengidentifikasi hubungan antara manajemen laba akrual dengan manajemen laba riil. Hasil uji korelasi pada periode setelah adopsi IFRS berbeda dengan hasil uji korelasi antar variabel pada periode sebelum adopsi IFRS. Hubungan antara biaya produksi abnormal dengan manajemen laba akrual setelah adopsi IFRS adalah signifikan positif $(0.026<0.05)$, sedangkan hubungan antara manajemen laba akrual dengan manajemen laba riil (RM_Proxy) adalah positif dan tidak signifikan. Hal ini disebabkan karena dalam proksi manajemen laba riil terdapat tingkat arus kas operasi abnormal yang hubungannya tidak signifikan dengan manajemen laba akrual.

Hasil di atas menunjukkan bahwa hipotesis ketiga yang menyatakan bahwa tingkat manajemen laba akrual berhubungan negatif dengan tingkat manajemen laba riil tidak terdukung secara statistik. Hubungan antara Akrual Diskresioner dengan Biaya Produksi Abnormal positif dan signifikan, sedangkan hubungan antara akrual diskresioner dengan Arus Kas Abnormal positif dan tidak signifikan. Hal ini juga ditegaskan kembali pada hubungan antara Manajemen laba akrual (Abs_DA) dan Proksi Manajemen Laba Riil (RM_Proxy) yang tidak signifikan pada periode sebelum dan setelah adopsi IFRS. Ada yang menarik dalam hasil pengujian hipotesis ketiga ini. Setelah IFRS, hubungan antara akrual diskresioner dengan biaya produksi abnormal menjadi positif dan signifikan, sementara pada periode sebelum adopsi IFRS hubungan keduanya negatif dan tidak signifikan. Hal ini yang menyebabkan hubungan antara seluruh proksi manajemen laba riil dengan manajemen laba akrual menjadi positif dan tidak signifikan pada periode setelah IFRS setelah sebelumnya berhubungan negatif. Hubungan positif antara manajemen laba akrual dan riil yang ditunjukkan pada penelitian ini menegaskan hasil penelitian yang telah dilakukan Lippens (2008). Ia menunjukkan bahwa terjadi 
peningkatan manajemen laba akrual dan riil pada periode setelah adopsi IFRS secara wajib.

Hasil pengujian hipotesis ketiga menunjukkan bahwa ketika manajemen laba akrual meningkat, maka manajemen laba riil juga meningkat setelah adopsi IFRS. Hubungan signifikan antara Arus Kas Operasi Abnormal dan Biaya Produksi Abnormal menunjukkan bahwa ketika manipulasi penjualan dilakukan dengan mempercepat penjualan tahun depan menjadi penjualan tahun berjalan, maka secara otomatis akan meningkatkan biaya produksi barang pada periode berjalan. Seharusnya ketika kondisi ekonomi normal, perusahaan tidak perlu melakukan manipulasi penjualan dan meningkatkan produksi. Temuan penelitian ini mengindikasikan bahwa IFRS tidak mampu mengurangi manajemen laba akrual dan riil. Hasil beberapa pengujian di atas menegaskan beberapa penelitian yang menyatakan bahwa IFRS tidak dapat meningkatkan kualitas angka akuntansi khususnya dalam upaya mengurangi manajemen laba.

Melihat ketiga hasil hipotesis di atas, maka pada bagian berikutnya ini akan memberikan beberapa analisis sensitivitas dan lanjutan untuk menegaskan hasil uji hipotesis yang telah dilakukan sebelumnya dan menjelaskan hubungan yang lebih detail antara manajemen laba akrual dan riil dengan adopsi IFRS. Beberapa pengujian dan analisis lanjutan yang dilakukan adalah menguji hubungan-hubungan berikut ini: Pertama, perbedaan manajemen laba akrual dan riil pada periode dua tahun sebelum dan setelah adopsi IFRS secara wajib. Kedua, Perbedaan manajemen laba akrual dan riil pada periode satu tahun sebelum dan setelah adopsi IFRS secara wajib;

Dari seluruh hasil analisis lanjutan yang dilakukan menunjukkan bahwa tidak ada perubahan tingkat manajemen laba akrual dan riil pada perusahaan yang mengadopsi IFRS secara wajib. Hasil analisis lanjutan yang dilakukan mendukung temuan pada hasil pengujian hipotesis. IFRS tidak berpengaruh terhadap perilaku manajemen laba riil. Tidak ada perbedaan antara tingkat manajemen laba riil sebelum dan setelah adopsi IFRS pada perusahaan yang mengadopsi secara wajib. Aktivitas-aktivitas riil perusahaan tidak berubah karena mengadopsi IFRS. IFRS adalah standar yang mengatur pengukuran, 
pengakuan, pencatatan dan pelaporan transaksi bisnis. IFRS bukan standar yang mempengaruhi aktivitas riil bisnis perusahaan secara langsung.

Hasil penelitian ini memberikan bukti empiris bahwa IFRS tidak memberikan dampak yang baik terhadap peningkatan kualitas angka akuntansi khususnya untuk mengurangi praktik manajemen laba. Bahkan tingkat manajemen laba akrual yang tinggi tetap terjadi pada periode setelah meretia mengadopsi IFRS secara wajib.

\section{SIMPULAN}

Penelitian ini bertujuan untuk memberikan bukti empiris mengenai praktik manajemen laba di Uni Eropa pada periode sebelum dan setelah adopsi IFRS secara wajib. Praktik manajemen laba yang diobservasi adalah manajemen laba akrual yang diproksikan dengan tingkat akrual diskresioner, dan manajemen laba riil yang diproksikan dengan arus kas abnormal dan biaya produksi abnormal. Penelitian ini menunjukkan secara empiris bahwa tidak ada perbedaan yang signifikan antara manajemen laba akrual dan riil pada periode sebelum dan setelah adopsi IFRS secara wajib. Hasil lain juga menunjukkan bahwa manajemen laba akrual dan riil menunjukkan korelasi yang positif dan signifikan untuk proksi biaya produksi abnormal setelah adopsi IFRS secara wajib.

Pada pengujian manajemen laba riil, tidak terdapat perbedaan antara manajemen laba riil pada periode sebelum dan setelah adopsi IFRS. Selain itu, penelitian ini juga menunjukkan bahwa hubungan antara manajemen laba riil dengan cara manipulasi penjualan dan meningkatkan persediaan dengan menambah tingkat produksi normal adalah positif. Dengan demikian tidak terdapat hubungan antara manajemen laba riil dengan adopsi IFRS.

IFRS sebagai standar akuntansi berterima internasional yang diharapkan mampu meningkatkan kualitas angka akuntansi, ternyata tidak demikian. Standar yang berdasarkan prinsip ini justru memberikan kelonggaran bagi perusahaan untuk melakukan judgement baik dalam memutuskan pilihan kebijakan akuntansi yang akan digunakan, maupun dalam hal aktivitas operasi riil yang dilakukan. Semua dilakukan manajer perusahaan berdasarkan berbagai motivasi yang telah disampaikan pada bagian sebelumnya. 
Periode penelitian yang masih terbilang singkat (tiga tahun sebelum dan tiga tahun setelah adopsi IFRS), dapat diperpanjang pada penelitian berikutnya dan menggunakan sampel yang lebih luas agar penelitian mendatang lebih komprehensif. Selain itu, penelitian berikutnya mungkin dapat menggunakan alat analisis lain seperti regresi berganda untuk melihat pengaruh adopsi IFRS terhadap manajemen laba. Variabel-variabel lain seperti ROA, Leverage, atau tingkat inflasi juga dapat ditambahkan dalam pengujian untuk melihat adanya variabel lain yang mempengaruhi tingkat manajemen laba akrual dan riil. Penelitian ini menguji manajemen laba akrual dan riil pada perusahaan yang menerapkan IFRS secara wajib. Untuk penelitian berikutnya perlu dilakukan dengan melihat dampak IFRS terhadap perilaku manajemen laba akrual dan riil pada perusahaan yang menerapkan IFRS secara sukarela.

\section{PUSTAKA ACUAN}

Ahmed, S.A, et.al. 2010. Does Mandatory Adoption of IFRS Improve Accounting Quality? Preliminary Evidence. Working Paper, Texas A\&M University.

Armstrong, C.S, et.al. 2010. Market Reaction to the Adoption of IFRS in Europe. The Accounting Review. Vol 85. pp 31-61.

Arifin, T. \& I.W. Kusuma. 2011. Comparing Earnings Management in Germany and the USA. International Journal Managament Bussines Research. Vol. 1. No. 2. pp. 59-68.

Aussenegg, W. et.al. 2009. Earnings Management and Accounting Standards in Europe. Proceedings of the 2009 MFA Annual Meeting.

Barth, M.E. et.al. 2008. International Accounting Standards and Accounting Quality. Journal of Accounting Research. Vol. 46. No. 3. pp. 467-498.

Callao, S \& J.I. Jarne. 2010. Have IFRS Affected Earnings Management in the European Union? Accounting in Europe. Vol. 7. No. 2. pp. 159-189.

Capkun, V. et.al. 2011. Does Adoption of IAS/IFRS Deter Earnings Management?. Working Paper. Versi 5/20/2011. http://ssrn.com/abstract=1850228

Cheng, G.I. et.al. 2005. Information Content and Timing of earnings Announcementts. Journal of Business Finance and Accounting. Vol. 43. No. 1. pp. 65-95. 
Christensen, H.B. et.al. 2008. Incentives or Standards: What Determines Accounting Quality Changes Around IFRS Adoption? AAA 2008 Financial Accounting and Reporting Section (FARS) Paper. http://ssrn.com/abstract=1013054

Cohen, D.A. et.al. 2008. Real and Accrual-based Earnings Management in the Preand Post-Sarbanex Oxley Periods. The Accounting Review. Vol. 83. No. 3. pp. 757-787.

Cohen, D.A. \& P. Zahrowin. 2008. Acrual-Based and Real Earnings Management Activities around Seasoned Equity Offerings. Finance Working Paper. http://ssrn.com/

Dechow, P.M, et.al. 1995. Detecting Earning Management. The Accounting Review. Vol. 70 No. 2. Hal. 193-225.

Decker, W.E. \& P. Brunner. 2003. Summary of Accounting Principle Differences Around the World. International Finance and Accounting Handbook. Edisi ketiga. Chapter 12.

Demski, J. 2004. Endogenous Expectation. The Accounting Review 79. pp. 519539.

Ewert, R. \& A. Wagenhofer. 2005. Economic Effects of Tightening Accounting standards to Restrict Earnings Management. The Accounting Review 80 (4). pp. 1101-24.

Fisher, M. \& K. Rosenzweig. 1995. Attitudes of Students and Accouting Pratitioners Concerning the Ethical Acceptability of Earnings Management. Journal of Business Ethics. Vol. 14. pp. 433-444.

Francis, J. \& K. Schipper. 1999. Have Financial Statements Lost Their Relevance?. Journal Accounting Research. Vol. 37. No. 2. pp. 319-352.

Gujarati, D.N. 1995. Basic Econometric. New York: Mc Graw Hill.

Hair, J.F. Jr. et.al. 2010. Multivariate Data Analysis: A Global Prespective. Edisi ke7. New York: Pearson.

Hartanti, D.W. 2010. Pengaruh Asimetri Informasi terhadap Manajemen Laba Akrual dan Riil Studi Empiris pada Perusahaan Manufaktur di Bursa Efek Indonesia. (Tesis Tidak Dipublikasikan). Yogyakarta: Universitas Gadjah Mada. 
Healy, P.M. \& J.M. Wahlen. 1995. A Review of Earnings Management Literature and its Implication for Standard Setting. Accounting Horizon. Vol. 13. pp. 365-383.

Hutagaol, A. 2009. Hubungan Pengadopsian IFRS dengan Kualitas Laba Akuntansi. (Tesis Tidak Dipublikasikan). Yogyakarta: Universitas Gadjah Mada

Lippens, M. 2008. The Mandatory Introduction of IFRS as a Single Accounting Standard in the European Union and the Effect on Earnings Management. Rotterdarm: Erasmus University Rotterdam

Pacter, P. 2003. International Financial Reporting Standards. International Finance and Accounting Handbook. Edisi ketiga. Chapter 16.

Rahmellia, A.S. 2009. Earnings Management dan Nilai Relevansi Laba sebelum dan Setelah Pengadopsian IFRS. (Tesis Tidak Dipublikasikan). Yogyakarta: Universitas Gadjah Mada.

Roychowdhury, S. 2006. Earnings Management Through Real Activities Manipulation. Journal of Accounting and Economics. Vol. 42. pp. 335-370. Santoso, S. 2010. Statistik Parametrik, Konsep dan Aplikasi dengan SPSS. Jakarta: Elex Media Komputindo.

Scott, W.R. 2000. Financial Accounting Theory, Ed. Kedua. Canada: Prentice Hall. Sulistiawan, D. et.al. 2011. Creative Accounting-Mengungkap Manajemen Laba dan Skandal Akuntansi. Jakarta: Salemba Empat.

Yu, W. 2008. Accounting-Based Earnings Management and Real Activities Manipulation. (Dissertation Unpublished). Georgia: Georgia Institute of Technology. 